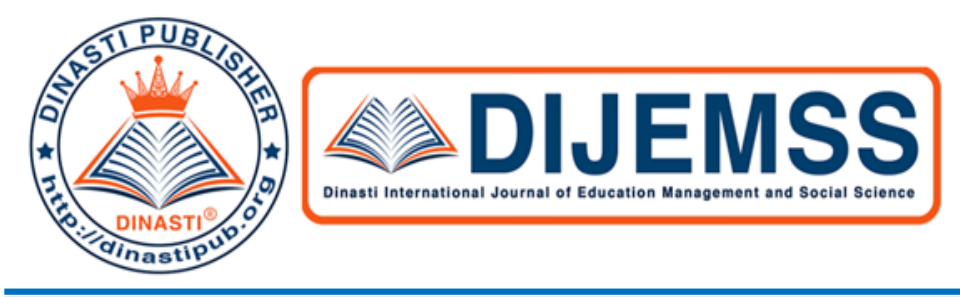

+6281387654578 (3)

+6281387654578 (Q)

https://dinastipub.org/DIJEMSS (-)

dinasti-info@gmail.com @.

\title{
THE ABILITY OF THE FIELD EXTENSION OFFICERS TO IMPLEMENT COMMUNICATIVE EXTENSION TEACHING TECHNIQUE IN JAMBI CITY
}

\author{
Denny Denmar ${ }^{1)}$, Ferdiaz Saudagar ${ }^{2)}$ \\ ${ }^{1,2)}$ Faculty of Teacher Training and Education, Universitas Jambi, Jambi, Indonesia
}

\begin{tabular}{|c|l|}
\hline $\begin{array}{c}\text { ARTICLE INFORMATION } \\
\text { Received: } 26^{\text {th }} \text { June } 2020 \\
\text { Revised: } 25^{\text {th }} \text { July } 2020 \\
\text { Issued: } 22^{\text {th }} \text { August } 2020\end{array}$ & $\begin{array}{l}\text { Abstract: The objective of the study is to find out the ability } \\
\text { of the field extension officers to implement communicative } \\
\text { extension teaching technique, knowledge of extension, } \\
\text { extension score, and creative attitude. The study was } \\
\text { conducted in Jambi Extension Center (2019) with 90 } \\
\text { respondents randomly selected. The study shows that there } \\
\text { are positive correlations between: 1) knowledge of extension } \\
\text { and the ability of the field extension officers to implement } \\
\text { Denny Denmar } \\
\text { communicative extension teaching technique; 2) extension } \\
\text { score and the ability of the field extension officers to } \\
\text { implement communicative extension teaching technique; } 3) \\
\text { creative attitude and the ability of the field extension officers } \\
\text { to implement communicative extension teaching technique. } \\
\text { In addition, there is a positive correlation between } \\
\text { knowledge of extension, extension score and creative } \\
\text { attitude \& the ability of the field extension officers to } \\
\text { implement communicative extension teaching technique } \\
\text { Thus, the ability of the field extension officers to implement } \\
\text { communicative extension teaching technique can be } \\
\text { enhanced by increasing knowledge of extension, extension } \\
\text { score, and creative attitude. } \\
\text { Keywords: The ability of the field extension officers, } \\
\text { knowledge of extension, extension score, creative attitude }\end{array}$ \\
\hline
\end{tabular}

\section{INTRODUCTION}

Nowadays, looking at the field extension officers' tendency through their work performance, the result of communicative extension becomes the main obstacle for people, students, and university students. Moreover, in the rapid development of telecommunication and movement towards the globalization era, communication skill (the most natural skill) is a demand. The success of learning process to achieve the goal of the field extension officers is really determined by many factors, such as teaching method. As we know, teaching and learning activities involve at least three components, namely student, teacher, and methodology, in addition to some factors like facilities, learning material, teaching equipment, learning environment, and so on. However, according to Gerard, the success of learning is mainly determined by the elements of methodology, especially the accuracy of teaching technique implemented by the teachers in the classroom. Learning technique 
involves at least three scientific disciplines, namely linguistics, psychology, and didacticmethod.

Linguistics provides information about the nature of language or spoken language and specific speaking styles of certain languages. Psychology describes how humans learn something. Meanwhile, education tries to process these two sciences into one ingredient commonly called learning method or technique applied by the teacher/the field extension officer-students during the interaction of teaching and learning on the field. The rationality is that the development of such sciences is in line with the development of teaching or extension strategy. Thus, the level of obsolescence and information of teaching method run rapidly. However, it is important to know that the change of one method into another method is not really bound, so the development of historically chronological teaching method only refers to the popularity of a method. This often results in a plurality of interpretations and doubts about its implementation in the classroom and on the field.

Based on a temporary conclusion obtained from the observation and opinion poll, it is seen that there are at least three learning strategies of combining extension process in the classroom and on the field.

The first group is the field extension officers who view that they have done innovation in communicative extension teaching technique by combining method. In other words, they know the benefits of each method, so combining those methods will best teaching technique. The second group is the field extension officers who do not know or do not really understand the characteristics of each method, so they only use the method that they know most for their teaching-learning activities. Furthermore, there is also a group of the field extension officers who theoretically understands understand several method of extension, but for some reasons like being busy, having difficulties in certain method, being unwilling to face changes, and so on. This group teaches the audience as best as they can and even sometimes teach without understanding the goals of learning. In general, extension activities are still influenced by the field extension officers' way of teaching in Agriculture Vocational High School. Thus, it is reasonable that the extension skills of students graduated from either Agriculture Vocational High School or 3-year Diploma in Extension have not been sufficient.

The formal task of the field extension officers is to teach students and the farming community to be able to communicate, both spoken and written, in a dialogue by applying teaching and learning process, especially using a reference of communicative approach. However, as it stated above, the situation shows plurality in the implementation in the Village Hall. It is caused by various factors, both lingual and non-lingual factors, such as the condition of the Village Hall, teaching equipment, the ability of the field extension officers, and so on. Therefore, to find the most influencing factor in teaching students, communicative extension method in this research is very necessary.

Based on the explanation above, there are some problems related to the implementation of teaching and learning process of communicative extension both in the classroom and on the field. Many factors are thought to have a correlation with the ability of the field extension officers to implement the communicative extension teaching technique, namely the feasibility of the method, the complexity of the curriculum, learning aids, the way of the field extension officers to implement a method, work discipline, and so on. However, it is almost impossible in this very limited opportunity to study all these problems. Therefore, the research will only focus on the knowledge factor about the communicative approach and learning condition in relation to the ability of the field extension officers to implement communicative extension teaching technique. To make this research operational, the problems are formulated as follows:

1) Is there a correlation between knowledge of extension and the ability of the field extension officers to implement communicative extension teaching technique? 
2) Is there a correlation between extension score and the ability of the field extension officers to implement communicative extension teaching technique?

3) Is there a correlation between creative attitude and the ability of the field extension officers to implement communicative extension teaching technique?

4) Is there a correlation between knowledge of extension, extension score, and creative attitude simultaneously \& the ability of the field extension officers to implement communicative extension teaching technique?

\section{THEORETICAL DESCRIPTION}

\section{The ability of the field extension officers to implement communicative extension teaching technique}

The concept of ability has been presented by scientists. Although the way of expressing it is different, the understanding is similar.

Ability is defined as one's maximum performance in doing some works. If the maximum performance is measured, one tends to do his job as well as possible, expecting the greatest result (Brumfit, 1984: 29).

Other scientists state that ability is one's maximum effort to do activities. Thus, to achieve the best result, one needs a high motivation. In other words, motivation will increase one's ability to achieve the maximum result (Morrow, 1986:278).

Rivers (1996: 85-86) also state that ability is one's capability to do something or to carry out duties both physically and intellectually. Basically, it is destiny that every human is different in both physical and psychological abilities.

In this research, the ability to implement communicative learning technique is the main factor in teaching communication to the students. The ability to implement communicative learning technique means the capability of the field extension officers to implement communicative extension teaching technique according to the theory and approach of communicative extension. Theoretically, there are three learning skills in extension (Rebecca, 1972:39-40), namely:

1) Separated learning of speaking skill and speech style, which is a technique that separates extension skills into learning and explaining while listening.

2) Learning prop skills that combine two skills in one activity, such as learning about connecting plant stems, cutting plant roots, and so on.

3) Integrated extension learning, which is a learning activity that combines a variety of farming skills packages into one package of learning (integrating skills).

Byrne (1982:108 - 125) states that the learning activities are detailed by dividing students into groups, and each group is given a discourse related to speaking and writing on farming needs. The group leader reads the discourse and the group members listen to rewrite the contents of the discourse. The results of the discourse summary are exchanged between farmer groups then read and discussed. Such extension activities can be varied according to circumstances.

\section{Knowledge of Extension}

During the extension activity, the field extension officers should have enough knowledge as a part of education. There are several approaches or methods. One of the approaches that are now being developed and implemented is non-formal education. This education is a principle that underlies the leadership style of the field extension officers in the Extension Center that should be understood by famers, cultivators, and breeders. Knowledge about the communicative approach to the audience is mastered by the field extension officers. They also master other sciences through a long process by taking Teaching and Learning strategy. 
In the beginning of its development, approach to the audience varies (multi facets), both formulation and basic principles. Dell Hymes (1975: 5-25) states that communicative ability is the mastery of giving comprehensive extension of the field extension officers to use and to understand farmers appropriately in a context. Goodman (1985: 6-7) mentions the field extension officers' language style as something whole. This expression implies that communicative extension is carried out in a background where students are. This view is not only based on verbal elements, but also socio-cultural rules in its use. In other words, verbal manners and social context are integral parts of extension skills.

Otler (1976: 5-20) argues that learning extension skills not only focuses on concepts and meanings, but also function and purpose of communication styles. Richard (1986: 27) assumes the nature of communicative method as a system of giving extension that functions to explain things, which are means of interaction.

\section{The Meaning of Extension Score}

Score is the subject's performance on a measurement scale expressed in numbers. This number is an answer to a question in a test (Azwar, 1977: 25). The test itself is a systematic instrument or procedure for measuring certain behavior (Grounland, 1985:5). More specifically, Manser states that behavior is one's knowledge or ability (Manser, 1991: 428). In the capacity of a test, the extension test (Score of the Five Farming Principles ranges 0 - 1,000) (Test of Land Clearing Etc) is a test used to evaluate the farming skills of students (http//www.Pancausahatani/score.html) (Agricultural Testing Service, 1996:4).

Farmer supervision is intended to measure one's ability to understand the learning outcomes from the field extension officers' dialogues. Listening Comprehension consists of three parts namely:

A. Short conversations which aim at apologizing, giving advice, or getting information

B. A 2-minute conversation about general issues and daily life of an audience, such as discussing the completion of lecture material report, savings and loan cooperative report, or buying an airplane ticket

C. A 25-minute lectures about obtaining explicit and implicit information, important information, summarizing the role of the field extension officers, the relationship between the speaker and his listeners

The field extension officers' expression is intended to measure the extent to which their ability in asking questions. It is to test one's ability to identify various field problems and to recognize mistakes in a standardized farming.

SWOT analysis is used to measure one's ability to understand traditional farming and farming techniques, including understanding of the main ideas and supporting ideas in identifying strengths, weaknesses, opportunities, and threats. The analysis is also used to know one's ability to make inferences based on the information contained in the extension material according to the context of the Five Farming Principles, for example. The total number of test on the five farming principles is 5 with a completion time of 25 minutes, and the number of correct answers is called the raw score. This raw score is then processed using a processed value of $0-1,000$ called plant preparation score 200, plant 200, weeding plant 200, fertilize 200, and irrigate 200. There is no criterion for the score limit to be said passed. However, there are standards that can be accepted in general, namely scores of 600 and above are categorized as a good farmer, 400 identifies that the farmers are not good, and below 400 identifies that the farmers are not good (Agricultural Education Service, 1996:4).

The scores of skills above are obtained from the Preparation Kit of the Five Farming Principles issued by the Department of Agriculture • Testing Service, 1995. 


\section{The Meaning of Creative Attitude}

Attitude is the way a person thinks, acts, or faces a situation (Barnhart, 1980: 132). In general, attitude is formed through imitation of whatever happens in their environment (Krench, 1988:138). If the environment where the imitation is limited, the types of attitudes will be limited as well (Holtzman, 1980:473). Thus, Holtzman states that one's attitude, which includes ways of thinking, acting, and feeling as mentioned above, actually tends to be influenced by the environment where he lives.

Creative is a situation where someone has the creative power or the ability to create something. This meaning shifts slightly based on the background or environment of someone who interpreted the origin of the creativity. People who come from the creative arts world interpret it as something that moves, while from the point of cultural evolution, it is interpreted as a genetic mutation (Csikszentmihaly, 1996:291). According to the perspective of education setting, Conny defines creativity as one's ability to make new combination or to see new relationship, or to see new relationship between elements of data that already existed (Semiawan, 1984:88). Meanwhile, Louis interprets it as an attempt by a teacher to teach students in various ways, such as carrying out various activities, using different teaching aids, and implementing learning systems (such as supportive learning groups, and learning with tutors) that can improve students' learning outcomes (Gestner Jr. 1995:154).

Actually, the four things above are related to each other. Someone is said to be creative if there are results or products that can be shown. The results or products become reality after going through various processes. The products will naturally be selected through measurement criteria, namely:

(a) Type of material or content of mind,

(b) Variety of activities or activities that are formed,

(c) Variety of products

Furthermore, all of the things mentioned above can only be realized if the person has a creative personality. Creative personality includes cognitive dimension (which refers to talents) and non-cognitive (which refers to interests, attitudes, and temperament qualities). Creative people have personality traits that are different from people who are less creative (Guitford, 1996: 22).

The characteristics of people with creative personality are:

1) Being sensitive to problems, meaning that they can see flaws, weaknesses, or mistakes in an object that other people do not see;

2) Being critical thinking, meaning that they are able to create many ideas that lead to problem solving;

3) Being flexible in thinking, meaning that they are able to provide diverse ideas, not afraid and persistent;

4) Having a controversial way of thinking, meaning that they can provide ideas that are not common/rarely done by others and can see broad view on associations and break away from the order of objects and situations;

5) Being able to redefine, meaning that they can give new meaning or formulation to an object or problem which can be used in a new way;

6) Being able to elaborate, meaning that they can develop an idea, concept or object as well as enrich and detail its parts;

7) Being able to evaluate, meaning that they can consider or assess objects, behavior or situations based on certain criteria (Guilford, 1970: 169).

Moreover, Munandar classifies the characteristics of creative personality into 10 aspects:

1) Being able to control the energy they own

2) Having a tendency of convergent and divergent thinking in a balanced way 
3) Being very disciplined in working and considering everything done as fun

4) Appreciating imagination and fantasy as valuable as reality

5) Having a tendency towards extroversion and introversion

6) Being humble and more confident

7) Having the good qualities of femininity and manhood

8) Having a tendency to be rebellious and independent

9) Having high motivation in working, but still being objective in giving or accepting assessment towards a work results

10) Being very open and sensitive to things that are considered not/less than perfect and being happy when successfully solving problems

In general, not everyone can do the 10 criteria explained by Munandar because:

a) Most people are interested in various things but cannot focus their interest on just one thing specifically

b) They are easily confused and difficult to learn to maintain the power that motivate the creative attitude

c) They are lazy and less disciplined to control the power to motivate the creative attitude

d) They do not know how to use their creative power (Munandar, 1996: 344).

Based on the two opinions above, it can be concluded that the 10 criteria are an extension of 7 Guilford criteria. If these 10 criteria are used to measure one's creative attitude, the results are expected to be more accurate. Therefore, in this study, Munandar's criteria are used as indicators to measure creative attitudes.

\section{RESEARCH FRAMEWORK}

The Correlation between Knowledge of Extension and the Ability of the Field Extension Officers to Implement Communicative Extension teaching technique

In the learning process, there are at leas three parties involved, namely the field extension officers, audience/students, and learning materials. From this concept, the field extension officers play an important role because these instructors are in control of determining the form and style of learning activities. Therefore, knowledge and insight of various methods and techniques of extension must be mastered. Learning method is based on communicative approach. The rationale is that the field extension officers are obliged to learn/to explore and to apply the method. The focus of material mastery is on communication skills based on verbal functions and leadership. Meanwhile, the demonstration tools/props is the supporting elements of the mastery of these skills and are not the main thing to be mastered. Thus, every communicative mastery learning activity is always prioritized.

Based on the description above, it can be assumed that there is a positive correlation between knowledge of communication approach and the ability to implement communicative extension teaching technique. This means that an increase in knowledge about the communicative approach will be followed by an increase in the ability to implement communicative extension teaching techniques or vice versa.

\section{The Correlation between Extension Scores and the Ability of the Field Extension Officers to Implement Communicative Extension Teaching Technique}

The ultimate goal of a field extension officer is to use his knowledge to communicate so that there are levels of accountability of farmers/students on their land. For the field extension officers, to communicate means to change the way the students farming for better production and to make them able to use their skill in agricultural machinery and equipment, that has been taught in the material as a subject.

Knowledge is a requirement that must be possessed by the candidates of field extension officers in order to teach farming and other skills to farmers/students. Good or poor 
skills of farming, taught by the field extension officers can be proven through the extension score. The extension score is one of the capability requirements.

There is no doubt that someone carrying out the task and knowing the problem well will be willing to do the task. If a field extension officer knows and deepens true about the theories and principles of communicative approach, and he deepens properly about the principles and learning objectives, it can be assumed that he will carry out the duties and responsibilities of a field extension officer without feeling burdened by the difficulties of teaching techniques.

Creative attitude of a field extension officer is the actualization of the description of human psychological power. The field extension officers who academically know and understand the communicative learning methods and techniques will respond positively to this approach. As a result, they will be to carry out communicative learning by not feeling burdened, and consider it part of their professional obligations. This awareness will be even more effective if it is supported by other elements, teaching media, and the environment, that illustrates the correlation of the three independent variables in facilitating the field extension officers in carrying out communicative extension teaching.

Based on the ideas above, it is assumed that there is a positive correlation between knowledge of extension, extension score, and creative attitude simultaneously \& the ability to implement communicative extension teaching technique.

\section{Research Hypothesis}

1. There is a positive correlation between knowledge of extension and the ability of the field extension officers to implement communicative extension teaching technique. In other words, the higher the knowledge of extension, the higher the ability of the field extension officers to implement communicative extension teaching technique is.

2. There is a positive correlation between extension score and the ability of the field extension officers to implement communicative extension teaching technique. In other words, the higher the extension score, the higher the ability of the field extension officers to implement communicative extension teaching technique is.

3. There is a positive correlation between creative attitude and the ability of the field extension officers to implement communicative extension teaching technique. In other words, the higher the creative attitude, the higher the ability of the field extension officers to implement communicative extension teaching technique is.

4. There is a positive correlation of knowledge of extension, extension score, and creative attitude simultaneously \& the ability of the field extension officers to implement communicative extension teaching technique. It means that the higher the knowledge of extension, extension score, and creative attitude, the higher the ability of the field extension officers to implement communicative extension teaching technique is

\section{RESEARCH METHODOLOGY}

This research aims to examine the correlation between:

1. Knowledge of extension and the ability of the field extension officers to implement communicative extension teaching technique

2. Extension score and the ability of the field extension officers to implement communicative extension teaching technique

3. Creative attitude and the ability of the field extension officers to implement communicative extension teaching technique

4. Knowledge of extension, extension score, and creative attitude simultaneously \& the ability of the field extension officers to implement communicative extension teaching technique 
The method used is a survey method that is carried out at Jambi City Extension Center. The research subject is the field extension officers. Data is collected using a research instrument consisting of 2 tests to collect data about knowledge of extension and extension scores, and 2 types of questionnaires to collect data about creative attitudes and the ability of the field extension officers to implement communicative extension teaching technique. Sample is selected using simple random sampling, and there are 90 field extension officers of a population of 120 people.

\section{Research Results}

To get a conclusion, hypothesis testing is done based on the calculation of the regression equation of significance and linearity test, correlation coefficient, significance test, partial correlation coefficient, and multiple correlation coefficient test. The following are the results of the research hypothesis test.

The correlation $\left(\mathrm{X}_{1}\right)$ between knowledge of extension and the ability of the field extension officers to implement communicative extension teaching technique (Y) is shown by the regression equation $\mathrm{Y}=21.1+0.74 \mathrm{X}_{1}$. The results of the significance and linearity tests of the regression equation are described as follows.

Table 1. Anova Table of Significance and Regression Linearity Test on the Ability of the Field Extension Officers to Implement Communicative Extension Teaching (Y) on the Knowledge of

\begin{tabular}{|c|c|c|c|c|c|c|}
\hline & & & tension ( & & & \\
\hline Variation & & & R IK & $\mathbf{F}_{\text {table }}$ & & \\
\hline source & DK & JK & RJK & & $\alpha \mathbf{0 . 0 5}$ & $\alpha 0.01$ \\
\hline Total & 90 & 1175299 & - & - & - & - \\
\hline Regression & 1 & 11547.6 & - & - & - & - \\
\hline (a) & 1 & 13523.5 & 13523.5 & 171.5 & 3.96 & 6.96 \\
\hline $\begin{array}{l}\text { Regression } \\
\text { (b/a) } \\
\text { Remaining }\end{array}$ & 88 & 7017 & 78.85 & - & - & - \\
\hline $\mathrm{F}_{\text {Count }}$ & 14 & 1107.5 & 79.1 & 1.0 & 1.82 .2 .03 & - \\
\hline Error & 74 & 5910 & 78.8 & - & - & - \\
\hline
\end{tabular}

Information:

DK : degrees of freedom

JK : number of squares

RJK : average number of squares

** : very significant regression

$\mathrm{N}^{8} \quad$ : linear regression

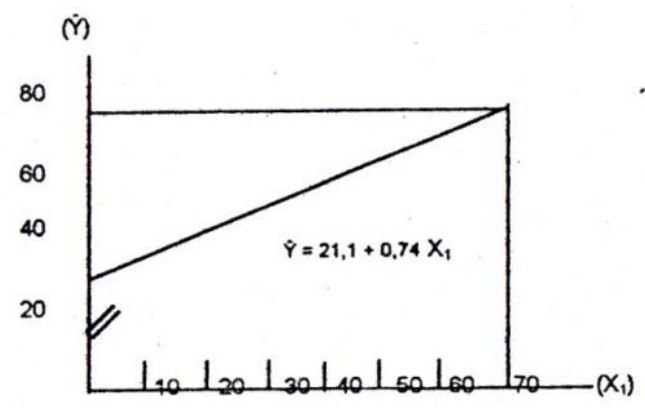

Figure 1. Regression Line Graph $Y=21.1+0.74 X$

Based on the significance and linearity test described above, it can be concluded that the regression equation $\mathrm{Y}=21.1+0.74 \mathrm{X} 1$ is significant and linear. The strength of correlation between knowledge of extension $\left(\mathrm{X}_{1}\right)$ and the ability of the field extension 
officers to implement communicative extension teaching technique $(\mathrm{Y})$ is shown by the correlation coefficient ry $1=0.61$. The coefficient test results in $f_{\text {count }}=9.5>f_{\text {table }}=2.0$ on the real level $\alpha=0.05$ which means that the correlation coefficient is significant. Coefficient of determination of $r_{2 y 1}=0.372$ means $37.2 \%$ of the variation in the ability of the field extension officers to implement communicative extension teaching technique $(\mathrm{Y})$ can be determined by knowledge of extension $\left(\mathrm{X}_{1}\right)$.

The correlation between extension score $\left(\mathrm{X}_{2}\right)$ and the ability of the field extension officers to implement communicative extension teaching technique ( $\mathrm{Y}$ ) is shown by the regression equation $\mathrm{Y}=29.7+0.88 \mathrm{X}_{2}$. The results of the significance and linearity tests of the regression equation are described as follows

Table 2. Anova Table of Significance and Regression Linearity Test on the Ability of the Field Extension Officers to Implement Communicative Extension Teaching (Y) on the Extension

\begin{tabular}{|c|c|c|c|c|c|c|}
\hline \multirow{3}{*}{$\begin{array}{c}\text { Variation } \\
\text { Source }\end{array}$} & \multirow{3}{*}{ DK } & \multirow{3}{*}{ JK } & \multicolumn{4}{|c|}{ Score $\left(\mathrm{X}_{2}\right)$} \\
\hline & & & \multirow{2}{*}{ RJK } & \multirow{2}{*}{$\mathbf{F}_{\text {table }}$} & \multicolumn{2}{|c|}{$\mathbf{F}_{\text {table }}$} \\
\hline & & & & & $\alpha 0.05$ & $\alpha 0.01$ \\
\hline Total & 90 & 1175299 & - & - & - & - \\
\hline Regression & 1 & 1154759 & - & - & - & - \\
\hline (a) & 1 & 5676.5 & 5676.5 & 33.99 & 3.96 & 6.96 \\
\hline $\begin{array}{l}\text { Regression } \\
\text { (b/a) } \\
\text { Remaining }\end{array}$ & 88 & 14864.5 & 167.0 & - & - & - \\
\hline $\mathrm{F}_{\text {Count }}$ & 28 & 1107.5 & 79.1 & 0.54 & 1.63 & 2.29 \\
\hline Error & 60 & 5910 & 78.8 & - & - & - \\
\hline
\end{tabular}

Information:

DK : degrees of freedom

JK : number of squares

RJK : average number of squares

** : very significant regression

$\mathrm{N}^{8} \quad$ : linear regression

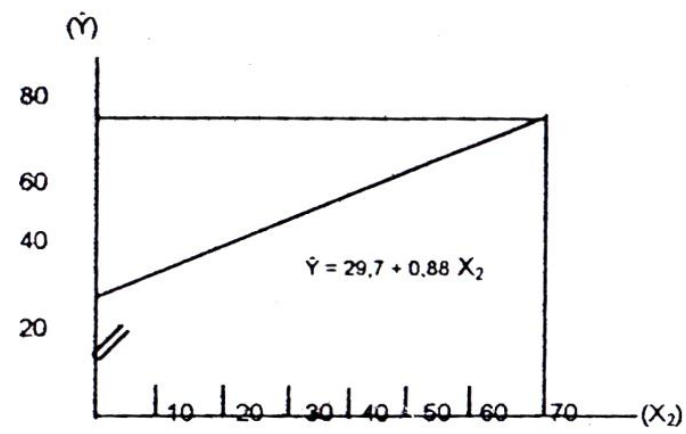

Figure 2. Regression Line Graph $\mathrm{Y}=\mathbf{2 9 . 7}+\mathbf{0 . 8 8} \mathrm{X}_{\mathbf{2}}$

Based on the significance and linearity test that has been described above, it can be concluded that the regression equation $\mathrm{Y}=29.7+0.88 \mathrm{X}_{2}$ is significant and linear. The strong correlation between extension score $\left(\mathrm{X}_{2}\right)$ and the ability of the field extension officers to implement communicative extension teaching technique $(\mathrm{Y})$ is indicated by the correlation coefficient $r_{\mathrm{y} 2}=0.53$, and the correlation coefficient obtains $t_{\text {count }}=0.357>f_{\text {table }}=2.0$ at the real level $\alpha=0.05$ which means that the correlation coefficient is significant. The coefficient of determination is $\mathrm{r}_{\mathrm{y} 2}^{2}-0.2809(.0281)$, it means that $28.1 \%$ of the variation in the ability of 
the field extension officers to implement communicative extension teaching technique can be determined by the Toefl score $\left(\mathrm{X}_{2}\right)$.

The correlation between creative attitude $\left(\mathrm{X}_{3}\right)$ and the ability of the field extension officers to implement communicative extension teaching technique (Y) is shown by the equation $\mathrm{Y}=38.6+0.83 \mathrm{X}_{3}$. The results of significance and linearity test- the regression equation is described as follows:

Table 3. Anova Table of Significance and Regression Linearity Test on the Ability of the Field Extension Officers to Implement Communicative Extension Teaching (Y) on the Creative

\begin{tabular}{|c|c|c|c|c|c|c|}
\hline \multicolumn{7}{|c|}{ Attitude $\left(\mathbf{X}_{3}\right)$} \\
\hline \multirow{2}{*}{$\begin{array}{c}\text { Variation } \\
\text { Source } \\
\end{array}$} & \multirow{2}{*}{ DK } & \multirow{2}{*}{ JK } & \multirow{2}{*}{ RJK } & \multirow[t]{2}{*}{$\mathbf{F}_{\text {tabel }}$} & \multicolumn{2}{|c|}{$F_{\text {tabel }}$} \\
\hline & & & & & $\alpha \mathbf{0 . 0 5}$ & $\alpha 0.01$ \\
\hline Total & 90 & 1175299 & - & - & - & - \\
\hline Regression & 1 & 1154758 & - & - & - & - \\
\hline (a) & 1 & 3200.9 & 3.200 .9 & 16.42 & 3.96 & 5.96 \\
\hline $\begin{array}{l}\text { Regression } \\
\text { (b/a) } \\
\text { Remaining }\end{array}$ & 88 & 17340.1 & 194.83 & - & - & - \\
\hline $\mathrm{F}_{\text {Count }}$ & 27 & 5344.1 & 197.93 & 1.02 & 1.73 & 2.50 \\
\hline Error & 61 & 11996 & 193.48 & - & - & - \\
\hline
\end{tabular}

Information:

DK : degrees of freedom

JK : number of squares

RJK : average number of squares

** : very significant regression

Ns : linear regression

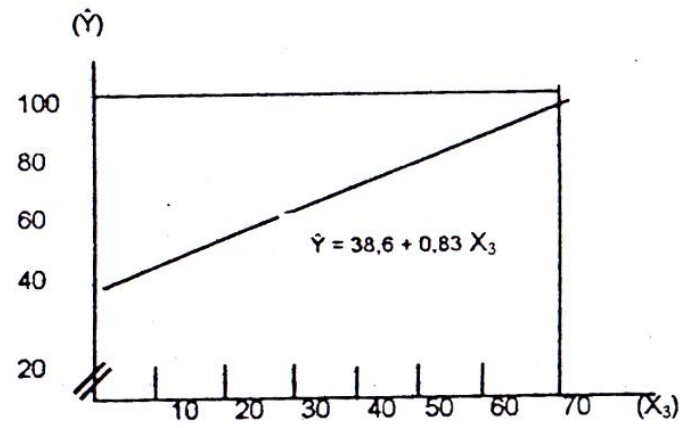

Figure 3. Regression Line Graph $\mathrm{Y}=\mathbf{3 8 . 6}+\mathbf{0 . 8 3} \mathrm{X}_{\mathbf{3}}$

Based on the Significance and Linearity test that has been described above, it can be concluded that the regression equation $\mathrm{Y}=38.6+0.83 \mathrm{X}_{3}$ is significant and linear. The strong correlation between creative attitude $\left(\mathrm{X}_{3}\right)$ and the ability of the field extension officers to implement communicative extension teaching technique $(\mathrm{Y})$ is shown by the correlation coefficient $r_{\mathrm{y} 3}=0.40$. Correlation coefficient test obtains $t_{\text {count }}=4.12>t_{\text {table }}=2.0$ at the real level $\alpha=0.05$ which means the correlation coefficient is significant. With a coefficient of determination of $\mathrm{r}_{\mathrm{y} 3}^{2}=0.16$, it means that $16 \%$ of the variation in the ability of the field extension officers to implement communicative extension teaching technique (Y) can be determined by creative attitude $\left(\mathrm{X}_{3}\right)$.

The correlation of knowledge of extension $\left(\mathrm{X}_{1}\right)$, extension score $\left(\mathrm{X}_{2}\right)$, and creative attitude $\left(\mathrm{X}_{3}\right)$ together \& the ability of field extension officers to implement communicative extension teaching technique $(\mathrm{Y})$ is shown by the multiple regression equation $\mathrm{Y}=0.88+$ 
$0.37 \mathrm{X}_{1}+0.51 \mathrm{X}_{2}+0.21 \mathrm{X}_{3}$. The results of the significance of the multiple regression equation are described in the following summary.

Table 4. Summary of Significance Test of Correlation of Knowledge of Extension $\left(X_{1}\right)$, Extension Score $\left(\mathrm{X}_{2}\right)$, and Creative Attitude $\left(\mathrm{X}_{3}\right) \&$ the Ability of Field Extension Officers to Implement Communicative Extension Teaching Technique (Y)

\begin{tabular}{|c|c|c|c|c|}
\hline \multirow{2}{*}{$\mathrm{Ry}_{123}$} & \multirow{2}{*}{$\mathrm{R}^{2} \mathrm{y}_{123}$} & \multirow{2}{*}{$\mathrm{F}_{\text {count }}$} & \multicolumn{2}{|c|}{$\mathrm{F}_{\text {table }} \mathrm{dk}=3 / 87$} \\
\cline { 4 - 5 } & & & $\alpha=5 \%$ & $\alpha=1 \%$ \\
\hline 0.67 & 0.447 & 23.44 & 3.96 & 4.04 \\
\hline
\end{tabular}

Based on the significance test described above, it can be concluded that the multiple regression $\mathrm{Y}=0.88+0.37 \mathrm{X}_{1}+0.51 \mathrm{X}_{2}+0.21 \mathrm{X}_{3}$ is significant (very significant), with the plural correlation coefficient $R_{y 123}=0.67$, while coefficient terminated for $R^{2}$ y123 $=0.447$. This means that $44.7 \%$ of the variation of the ability of the field extension officers to implement communicative extension teaching technique $(\mathrm{Y})$ is determined by knowledge of extension $\left(\mathrm{X}_{1}\right)$, extension score $\left(\mathrm{X}_{2}\right)$ and creative attitudes $\left(\mathrm{X}_{3}\right)$ simultaneously.

To determine the order of influence of each independent variable on the the ability of field extension officers to implement communicative extension teaching is described as follows.

Table 5. Table of Summary of Partial Correlation of Variable $1\left(X_{1}\right)$ by Controlling $\left(X_{2}\right)$ and $\left(X_{3}\right)$, Variable $2\left(X_{2}\right)$ by Controlling $\left(X_{1}\right)$ and $\left(X_{3}\right)$, Variable $3\left(X_{3}\right)$ by Controlling $\left(\mathbf{X}_{1}\right)$, and $\left(\mathbf{X}_{2}\right)$ towards $(\mathbf{Y})$

\begin{tabular}{|c|c|c|}
\hline $\begin{array}{c}\text { Number of Observation } \\
(\mathbf{N})\end{array}$ & $\begin{array}{c}\text { Partial Coefficient } \\
\text { Correlation }\end{array}$ & Rank \\
\hline 90 & Ry1.23=0.48 & The first \\
90 & Ry2.13=0.35 & The second \\
90 & Ry3.12=0.22 & The third \\
\hline
\end{tabular}

Based on the explanation above, it can be concluded that the influence of the first rank is knowledge of $r_{y 1.23}=0.48$, the second rank is extension score $\left(X_{2}\right)$ with $r_{y 2.13}=0.35$, and the third one is creative attitude $\left(\mathrm{X}_{3}\right)$ with $\mathrm{r}_{3.12}=0.22$.

Reviewing the contribution of each independent variable, the order is knowledge of extension $(37.2 \%)$, followed by extension score $(28.1 \%)$, and creative attitudes $(16 \%)$.

\section{CONCLUSION, IMPLICATION, AND SUGGESTION Conclusion}

Based on the results of research, it can be concluded that:

First, there is a positive correlation between knowledge of extension and the ability of the field extension officers to implement communicative extension teaching technique $\left(\mathrm{r}_{\mathrm{yt}}=\right.$ $\left.0.61 ; r^{2}{ }_{y t}=0.372 ; \alpha=0.05\right)$. This means that the higher the knowledge of extension owned by the field extension officers, the higher their ability to implement communicative extension teaching technique. The contribution given by the knowledge of extension factor to the ability of the field extension officers to implement communicative extension teaching technique is quite significant as indicated by the coefficient of determination, which is equal to $37.2 \%$.

Second, there is a positive correlation between extension score and the ability of the field extension officers to implement communicative extension teaching technique $\left(r_{\mathrm{y} 2}=0.53\right.$ $\left.1^{2}=0.218 ; \alpha=0.05\right)$. This means that an increase in extension scores will be followed by an increase in the ability of the field extension officers to implement communicative extension teaching technique. The lower the extension score, the lower the ability of the field extension officers to implement communicative extension teaching technique is. The contribution made by the extension score is quite significant as indicated by the coefficient of determination, which is equal to $28.1 \%$. 
Third, there is a positive correlation between creative attitude and the ability of the field extension officers to implement communicative extension teaching technique $\left(\mathrm{r}_{\mathrm{y} 3}=\right.$ $\left.0.40 ; r_{\mathrm{y} 3}^{2}=0.16 ; \alpha=0.05\right)$. This means that the increase of creative attitude will be followed by the increase of ability of the field extension officers to implement communicative extension teaching technique. Conversely, the lower the creative attitude, the lower the the field extension officers to implement communicative extension teaching technique is. The contribution made by the creative attitude is quite significant as indicated by the coefficient of determination, which is $16 \%$.

Fourth, there is a correlation between knowledge of extension, extension score, creative attitudes simultaneously and the ability of the field extension officers to implement communicative extension teaching technique $\left(\mathrm{R}_{\mathrm{y} 123}=0.67 ; \mathrm{R}_{\mathrm{y} 123}^{2}=0.447 ; \mathrm{a}=0.05\right)$. This means that if the three independent variables increase together, it will also be followed by an increase of the ability of the field extension officers to implement communicative extension teaching technique. The contribution of the three independent variables amounted to $44.7 \%$, which means that $55.3 \%$ of the variation of the ability of the field extension officers to implement communicative extension teaching technique is determined by other factors. In addition, it can also be concluded that there is a correlation of each independent variable and the ability of the field extension officers to implement communicative extension teaching technique, namely knowledge of counseling, extension score, and creative attitude.

\section{Suggestions}

First, the knowledge of extension factor and the ability of the field extension officers in learning - must have serious attention.

Second, the implementation of learning by the field extension officers (extension score) must be improved because, based on the results of this study, the implementation of learning has not been carried out professionally.

Third, based on the details of coefficient of determination, knowledge of the field extension officers provides the largest contribution in improving their skills.

Fourth, the field extension officers should implement more learning techniques.

Fifth, to create a learning atmosphere, diverse learning facilities and infrastructure are needed. This will not only increase the effectiveness of learning process, but also help and facilitate the tasks of the field extension officers.

Sixth, based on the author's knowledge, this kind of study has only been carried out this time, so the stability and reliability of conclusions and implications still need to be studied and tested more. It may be necessary to carry out a replication study by raising different population and sample sizes both qualitatively and quantitatively.

\section{REFERENCES}

Azwar,Saifuddin. 1997. Reabilitas dan Validitas. Yogyakarta: pustaka pelajar Offset.

Byme, Donn 1982. "Integration Skills" dalam Johnson, keith dk (peny.), Communication in the classroom. Burnt Hill : Logman.

Brumfit, Christoper.1984. Communicative and Method Teaching: The Roles of Fluency and Accuracy. Cambridge : Cambridge University Press, 1984.

1983. The Paractice of Communicative Teaching. Oxford:Pergamon.

CsikszenmihLY, Mihaly.1996. Creativity: Flow and The Psycology of Discovery and Invention. New York: Harper Collins Publisher Inc.

Goddman, 1995. Attitude and Motivation in Second Laguage Learning, Massachusetts: Newbury House Publisher.

Gestner Jr, Louis V. et al.1995, Reinventing Education: Enterpreneurship in America's public Scools. USA: A Plume Book. 
Golan, Stuart E., 1873, "Psychology Study of Creativity", Creativity: Theory and Research, (ed). Morton Bloomberg, USA: New Haven Conn.

Grounland, Norman E.1985, Measurement and Evalution In Teaching. New York: Macmilan Publishing Company.

Guilford, JP., 1970/1996, "Traits of Creativity" Dalam P.E. Vemon (ed). Creativity. England: Penguin.

Holtzman, Wayne H. dkk, 1980, Introduction to Psychology,university of Texas Austin, Harpier and and Rau, Publlsher: New York.

Hymes, D., 1975, “On Communicative Competence” dl. Pridje J.P.,\& Holmes, J. Sociolingiustics. Middlesex : Pinguin Books, Ltd.

Intro, Telt Team Aims. 1999, Teaching A Mix Ability Class, http: www.ecst. Csuchico. edu/sabuse/mix/8-3-1.html.

Krench, David.,1988, Crutchfield, Richard S dan Ballachey Egorton L. Individual in Society, Mac Graw Hill Book Company.

Krashen, S. D.,1981, Second Language Learning. Oxford: pergamon press.

Littlewood, Wiliam.,1981, Communicative Language Learning: An Introduction. Cambridge : Cambridge University Press

Manser, Martin H.,1991, Oxford Pocket Dictionary. London:Oxford University Press.

Mayesky,Mary.1990 Creativity Activites for Young Children. USA: Delmar Publisher Inc.

Mckinley, R. L. 1996, "An Introduction to Item Response Theory: Measurement and Evalution in Counseling and Development, Vol. 22 No. 1, p.p. 37-57" Buletin of Information for TWE and TSE. Princeton USA: ublication PO Box 6154.

Munandar, S.C.U.,1996, Mengembangkan Kretivitas Anak Berbakat. Jakarta: Depdikbud.

Morrow, Keith., 1988, "Principles if Cmmunicative Method" dl. Johnshon \& Keith dk. (ed)., Communication In the Classroom. Burnt Hill: Logman.

Oller, Jr.,J.W., 1976,Technic Language Test at school.London: Logman.

Richards, Jack J.,1986,"Comunicative Needs in Foreign Language Teaching Journal. Singapore: SEAMEO,RELC.

Rivers, Wilga, 1972, Speaking in Many Tounge. Massachusetts: Newbury House Pres.

Rebecco,1972, Teaching Skills. Chicago: The University Press.

Semiawan, Conny,1997, Perspektif Pendidikan Anak Berbakat. Jakarta:PT.Grasindo.

Semiawan, Conny. Dan Munandar, A.S., Munandar, S.C.U. 1984, Memupuk Bakat dan Kreativitas Siswa Sekolah Menengah. Jakarta: PT. Gramedia.

............. 1995, The Official Guide, Test Prepation Kit. Worbook. Princeton, N.J:085416151 USA. terjemahan

1997, Agricultural Testing Service. Bulletin of Information IPB. terjemahan

Woworumaya.1983, "Banyak Pengajar Menerapkan Metode Yang Keliru”. Jakarta: Kompas, 26 Agustus 1983. 